\title{
DEKONSTRUKSI MOTIF BATIK KERATON CIREBON: PENGARUH RAGAM HIAS KERATON PADA MOTIF BATIK CIREBON
}

\author{
Agus Nursalim ${ }^{1}$ Harry Sulastianto \\ Art and Educatin Department Faculty of Art And Design \\ Indonesia University of Education \\ E-mail: ans.sidiqp@gmail.com
}

\begin{abstract}
ABSTRAK
Motif batik Keraton Cirebon memiliki makna simbolik dan filosofis yang mengandung pesan moral. Ide dasar batik keraton adalah dari ragam hias Keraton Cirebon, naskah dan mushaf Al-qur'an pada Abad 20. Tekanan dan resistensi kebudayaan barat pada dekade 70 -an yang bersifat progresif utopis telah mengubur berbagai tradisi dan kebudayaan etnik, identitas lokal, subculture, yang dianggap tidak sesuai dengan semangat zaman modern. Arus informasi global telah memperkaya cakrawala pengetahuan lokal yang mampu membangkitkan kesadaran lokal yaitu kesadaran ontologism diantara kebudayaan plural yang imperialis dan represif yang akan menggiring pada krisis identitas. Identitas, menurut Jonathan Rutherfort merupakan satu mata rantai masa lalu dengan hubunganhubungan sosial, kultural, dan ekonomi di dalam ruang dan waktu satu masyarakat hidup. Kini motif batik keraton telah menjadi identitas batik Cirebon. Penelitian ini bersifat diskriptif kualitatif yang mengkaji hingar bingarnya era kebangkitan kembali motif batik keraton Cirebon setelah mengalami 'mati suri' selama berpuluh-puluh tahun. Permasalahannya adalah: Bagaimana pola ragam hias Keraton Cirebon mengalami dekonstruksi menjadi motif batik keraton Cirebon? Apakah makna filosofis dan makna simbolik motif Batik Keraton mengalami dekonstruksi setelah berkembang pesat menjadi batik Cirebon? Teknik Pengumpulan data dilakukan dengan cara: observasi, wawancara dan dokumentasi. Sedangkan Analisis data hasil penelitian dilakukan dengan pendekatan teori 'semiotika dekonstruktif' dari Jaques Derida dan Ferdinand de'Sausure. Kajian terhadap bahasa dan makna (petanda) simbolik dilakukan dengan teorinya Ferdinand de'Saussure. Sedangkan; penafsiran makna 'logos' menggunakan pendekatan teori semiotika dekonstruktif Jaques Derida. Dari hasil penelitian diperoleh informasi secara akurat dan benar mengenai proses dekonstruksi bentuk ragam hias ke dalam motif batik keraton hingga menjadi 'building character Batik Cirebon' beserta makna-maknanya yang telah didukung oleh teori-teori yang ada.
\end{abstract}

Kata kunci: dekonstruksi, motif, batik keraton, Cirebon

\begin{abstract}
The batique design of Cirebon Palace has a symbolic meaning and philosophic which contains a moral message. The basic idea of Cirebon Palace is decoration style of Cirebon Palace itself, manuscript and Al-Qur'an Mushaf on 20th century. The Pressure and resistance of western culture on the 70th decade which has utopian progressive characteristic have. Buried several tradition and ethnic culture, local identity, subculture, that is assumed it is not suitable with the spirit of modern era. The flow of global information have enriched a heavens of local knowledge that can get up local awareness that is ontologism awareness between plural culture which is imperials and repressive that also carrying to the crisis of identity. Identity itself according to Jonathan Rutherford was a linking of past with social relationship, cultural and economic in a space and time in a societies' life. Today, batique design of the palace had become an identity of Cirebon Palace. The research has descriptive qualitative which study the noise resurrection of batique design of Cirebon Palace after being a dead for a while during more than decades. The problem is how about the decoration style of Cirebon Palace had ever been deconstruction after grew become the batique motif of Cirebon Palace? What is philosophy meaning and symbolic meaning of batique motif of Cirebon Palace? The data collecting techniques are observation, interview and documentation. Meanwhile, result analysis of research is done by theory approach, "semiotic deconstructive" from Jaques Derida and Ferdinand de' Sausure. The study through languages and meaning (signer) symbolic is done by Ferdinand de'Sausure's theory. Meanwhile: interpretation meaning of 'logos' used approach of semiotic deconstructive theory of Jaques Derida. From the research outcomes, it is gained information accurately and exactly about the deconstruction process of decoration form style into batique motive of the Palace until become "building Character of Batik Cirebon" and their meaning supported by the many theories.
\end{abstract}

Keywords: deconstruction, motive, Batique Palace, Cirebon 


\section{PENDAHULUAN}

Banyak literature mengatakan batik sebagai mata dagangan mempunyai pemakai dalam jumlah banyak dan mencakup wilayah pasar yang luas. Tetapi batik klasik yaitu batik yang dipengaruhi oleh nilai tradisi Jawa dan didukung oleh kalangan bangsawan keraton Yogyakarta dan Surakarta tidak demikian halnya. Batik klasik atau batik keraton dibuat untuk mewujudkan nilai-nilai budaya Jawa. Dalam budaya Jawa khususnya di lingkungan keraton terdapat ketentuan-ketentuan yang menyangkut keluarga raja dan pejabat keraton dalam bertindak, berbicara dan berpakaian agar sesuai dengan aturan keraton. Keraton memandang perlu untuk membuat aturan supaya kedudukan raja tetap kuat dan mutlak.

Sikap mental yang memperlakukan secara khusus orang-orang tertentu karena usia atau kedudukannya dinyatakan Hasanudin (2001:p. 22) sebagai feodalisme: feodalisme tampak pada bahasa Jawa yang bertingkattingkat kasar (rendah), sedang dan halus (tinggi).

Aturan keraton yang merupakan upaya penghalusan kehidupan dalam sehari-hari di keraton tercermin dalam Dasa Sila Keraton : ngadi saliro, ngadi busono, ngadi jiwo, ngadi logo, wisastro, udo negoro, toto kromo, toto coro, susilo, dan utomo. Dalam praktek keseluruhan sila itu harus terpadu menjadi satu sebagai upaya penghalusan. Philip Kitley seorang peneliti berkewarganegaraan Belanda menyatakan bahwa aturan-aturan yang melarang corak-corak batik tertentu didasarkan atas pertimbangan feodalistik, raja mengemukakan bahwa batik telah kehilangan sifat-sifat eksklusifitasnya yang dahulu, karena kini dibuat oleh perajin Jawa (di luar keraton). Pangkal atau kedudukannya tidak lagi dihubungkan dengan produk itu sendiri, dan rumah tangga kerajaan terpaksa membuat rancangan pola dikerjakan secara teliti dan terperinci untuk menunjukkan para pemakai batik dari kelurga kerajaan dan membedakan mereka dari pemakai yang lain
(Philip Kitley, 1987).

Pendapat tersebut ditegaskan oleh Sudjoko (1983) bahwa salah satu aturan yang melarang pemakaian corak batik tertentu yang dinyatakan oleh Paku Buwono III (Kasunaan Surakarta), sebagai berikut: Anadene kang arupo jajarit kang kalebu ing larangan ingsun: batik sawat, lan batik parang rusak, batik cumangkiri kang calacap modang, bangun tulak, lenga teleng, daragem, lan tumpal. Anandene batik cumangkkirang ingkang acalacap lung-lungan atawa kakembangan, ingkang ingsun kawenangaken anganggoha papatih ingsun, lan sentananingsun kawulaningsun wedana.(Adapun jarit yang termasuk dalam larangan saya adalah; batik sawat dan batik parang rusak, batik cumangkiri yang berupa motif modang, bangun tulak, lenga teleng, daragem dan tumpal. Adapun batik cumangkirang yang berupa motif lunglungan, atau kekembangan(motif bunga) saya izinkan dipakai para patih saya dan keluarga bangsawan dan abdi dalem wedana).

Masa kejayaan batik di keraton Mataram (Ngayogyakarta) dan keraton Paku Buwana III (Keraton Kasunanan Surakarta) tidak diikuti oleh perkembangan batik di keraton Cirebon. Justru di masa itu batik keraton Cirebon mengalami masa surut dikarenakan terjadinya berbagai macam masalah seperti kelaparan, wabah penyakit, kerusuhan sosial, dan emigrasi masal. Musibah ini terjadi karena penjajahan Jepang dan Belanda yang merubah pola tanam dari tanaman padi diganti dengan tanaman kopi, gula, tarum, teh, dan cengkeh. Sehingga Cirebon mengalami masa susah yang berkepanjangan. Kegiatan membatik di keraton Cirebon dimasa itu beralih ke desa Trusmi $7 \mathrm{~km}$ ke arah barat untuk menghindari permusuhan, para perajin batik Trusmi pada awalnya merupakan sekelompok orang yang mendalami ilmu tarikat dan tergabung dalam sebuah wadah tarikat Naqsabandiah wal Qodiriah yang dipimpin Panembahan Trusmi yang belakangan dikenal sebagai Pangeran 
Tjakrabuana: (Irianto, Bambang: 2009).

Berkaitan dengan melunturnya identitas ini, ada satu paradoks yang merupakan warisan dari wacana pembangunan nasional (modernisasi) sejak empat dasa warsa terakhir ini. Pembangunan telah membentuk intregitas (penyeragaman) sosial dan sistem normatif yang berskala nasional yang pada gilirannya akan melemahkan sistem normatif dan adat yang bersifat lokal. Namun pada kenyataannya sistem sosial dan normatif yang berskala nasional ini tidak cukup kuat untuk menahan pengaruh luar seperti yang terjadi pada era informasi pada ekonomi global dewasa ini.

Jurgen Habermas dan Ernest Gellner punya pandangan yang berbeda mengenai identitas. Ia melihat bahwa keutuhan atau bahkan krisis identitas sangat tergantung pada adanya intregasi sosial dan sistem normatif yang memiliki legitimasi dan menjadi konsensus dalam satu sistem sosial. Krisis identitas muncul ketika struktur sosial menawarkan kemungkinan pemecahan masalah yang lebih kecil jika dibandingkan dengan yang harusnya tersedia bagi satu sistem identitas tersebut. Krisis dapat dianggap sebagai gangguan terhadap integrasi sistem sosial tersebut (Habermas dan Gelner; 1988)

Di dalam wacana pluralisme perkembangbiakan identitas-identitas dan perkembang-biakannya dimungkinkan sebagai akibat dari melunturnya tabu sebagai tapal batas idiologis bagi eksistensi satu identitas yang esensial. Tabu sebenarnya memiliki fungsi yang sangat sentral dalam upaya perumusan dan pembentukan dunia wujud, disebabkan fungsinya sebagai referensi dalam proses representasi sosial. Tabu merupakan satu mekanisme sosial yang bersifat abstrak dan berfungsi memberi batasan-batasan bagi satu komunitas tertentu dalam mengekspresikan atau merepresentasikan diri melalui obyek yang mereka ciptakan, atau melalui bahasa yang mereka ciptakan. Tabu dikonstruksikan untuk memberikan rambu-rambu mengenai apa yang pantas, kurang pantas dan tidak pantas untuk dilihat, dilakukan, atau direpresentasikan melalui citraan obyek dalam satu sistem sosial. Tabu menjaga integritas satu sistem sosial dan kelanggengan satu identitas. Mengendurnya nilai moralitas, tabu, spiritual dan mitologis telah membuka jalan bagi perkembangan bentuk-bentuk kebudayaan dan seni yang merupakan ungkapan keinginan untuk men'deskonstruksi'kan dan melepaskan diri dari apa-apa yang dianggap normal-yang etis, yang intelek, yang estetis. Kebudayaan dan seni dalam hal ini melepaskan diri dari identitas moral, intelektual dan estetika yang esensial dan orisinal namun tetap membawa identitas secara diskursif ke dalam identitas yang disarati oleh sifat-sifat abnormalitas, penyimpangan, pengaburan, penopengan, dan pembajakan identitas. Seperti halnya perkembangan batik Trusmi yang meroket bagai kacang yang meninggalkan kulitnya. Batik Trusmi telah mendeskonstruksikan keajegan, kemapanan, keberadaan budaya keraton yang direpresentasikan dalam motif batik kraton. Fenomena penormalan yang abnormal sebenarnya sudah berlangsung sejak lama, namun ia merupakan unsur yang dominan dalam kebudayaan dan seni masa kini di Cirebon, maka peruntuhan kategori-kategori dan oposisi-oposisi logis yang sebelumnya diterima secara umum dan pengesahan apa-apa yang abnormal dan terlarang menjadi normal dan tidak tabu. Pelepasan kebudayaan dan seni dari tabu dan normalitas telah membentuk wajah kebudayaan dan seni batik Trusmi yang mengaburkan identitas dan mengelabuhi realitas.

Permasalahan; yang menjadi pertanyaan adalah benarkah perkembangan batik Trusmi, batik Plumbon, batik Kenduran, batik Paoman (yang tergolong batik Cirebonan) dalam memproduksi telah melampaui batas 
tabu yang dianggap normal-yang etis, yang intelek, yang estetis (dari segi teknis, motif dan pewarnaan) terhadap kebudayaan keraton Cirebon yang di representasikan pada ragam hias keraton Cirebon?

Penelitian tentang perkembangan motif batik Cirebon kecuali mengkaji tentang berbagai motif batik keraton Cirebon dan motif batik Cirebon juga menyangkut berbagai kajian tentang makna simbolik dan filosofis motif batik itu sendiri. Mengkaji mengenai makna filosofis dan makna simbolik tentu dilakukan dengan suatu pendekatan. Pendekatan tafsiran menurut Jhon Sturrock (1979) mengutip pendapat Jaques Derrida, dilakukan dengan dua pendekatan. Pertama, pendekatan tafsiran retrospektif yaitu upaya-upaya bagi rekonstruksi makna atau kebenaran aslinya. Ke-dua, tafsiran prospektif, yaitu yang secara eksplisit menerima ketidakpastian makna. Berkaitan dengan kajian makna filosofis dan simbolis motif batik keraton keduanya dapat digunakan sebagai pendekatan kajian. Pendekatan retrospektif lebih tepat dalam kajian logos yaitu disebut kebenaran mutlak. Tafsiran prospektif memiliki pemahaman yang lebih bebas tanpa terikat pada dogma. Penelitian ini bertujuan mengetahui secara mendalam bagaimana pola ragam hias Keraton Cirebon mengalami dekonstruksi menjadi motif batik keraton Cirebon? Kecuali itu penulis juga ingin mengetahui kebenaran informasi berkenaan dengan makna filosofis dan makna simbolik motif Batik Keraton yang mengalami dekonstruksi setelah berkembang pesat menjadi batik Cirebon?

\section{METODE PENELITIAN}

Penelitian ini bersifat deskriptif, yaitu mendeskripsikan karakteristik atau ciriciri kelompok, kejadian atau fenomena (Alwasilah, 2002: 151). Terkait dengan lingkup dan batasan penelitian, penelitian ini tergolong kajian bersifat makro dengan membahas berbagai aspek diantaranya; jenis motif batik, memahami makna simbolik dan makna filosofis motif batik tersebut. Penelitian dilakukan di beberapa wilayah studi, yaitu di Keraton Kasepuhan Cirebon, Keraton Kanoman dan Desa Trusmi sebagai pusat pelestarian dan pusat industri batik Cirebon. Kecuali itu studi juga dilakukan di Keraton Surakarta dan Keraton Kasultanan Yogyakarta, di Pasar Klewer Surakarta, Pasar Bringharjo Yogyakarta sebagai pusat perdagangan batik terbesar di Indonesia serta di perpustakaan Keraton Kasunanan, Keraton Kasultanan dan perpustakaan Daerah di wilayah-wilayah daerah Jawa Barat. Berdasarkan permasalahan yang diajukan dalam penelitian ini, yang menekankan pada makna simbolik dan makna filosofik, kecuali itu penelitian ini diarahkan pada pergeseran makna yang juga menyangkut masalah persepsi sehubungan dengan berbagai ragam motif batik Keraton, maka bentuk penelitiannya adalah penelitian kualitatif.

Penelitian ini menggunakan Pendekatan teori Semiotika Dekonstruktif (Derida, De'Saussure, 1974) dalam tafsiran retrospektif dan prospektif, karena penelitian ini terdiri dari beberapa wilayah studi dan dalam wilayah semiotika motif batik serta pemahaman makna filosofis yang mendalam. Maka informasi dari beberapa wilayah tersebut akan disatukan dalam analisis untuk merumuskan kesimpulan studi, maka penelitian ini merupakan penelitian studi kasus ganda (Yin, Robet K. 1991). Teknik pengumpulan data dilakukan dengan: interview, observasi, dan studi dokumentasi, ini dilakukan untuk mengumpulkan data yang bersumber dari arsip dan dokumen yang ada dimana kegiatan tersebut dilakukan. Yang dimaksud dokumen dalam penelitian ini adalah barang yang tertulis (barang koleksi Keraton, motif batik, foto-foto ragam hias, dll.) atau terdokumentasikan selain records yang tidak disiapkan khusus atas permintaan peneliti (Alwasilah, 2002: 155). 
Kajian teori dalam penelitian ini: Batik merupakan salah satu jenis kebudayaan asli Indonesia yang telah menempuh parjalanan yang lama. Dugaan bahwa sejak zaman prasejarah pembuatan batik sudah dimulai adalah berdasarkan kenyataan bahwa tradisi batik kuno sampai sekarang masih dipakai dipedalaman yang terasing. Kain simbut dari Priangan adalah contoh batik asli yang dibuat dari bahan kanji sebagai perintang kain yang kemudian dicelup dengan zat pewarna alam dari jenis tumbuh-tumbuhan sudah dilakukan sejak zaman prasejarah. Jika dilihat jenis ragam hiasnya, motif batik Indonesia banyak bersumber dari ragam hias zaman prasejarah yaitu ragam hias geometris dan ragam hias perlabangan (Yudoseputro, 2009). Pada zaman Hindu keberadaan seni batik makin jelas, bahkan motif batik gringsing dan motif ceplok sudah dikenal pada kesenian Dongsong dan pedalaman Banten. Kecuali itu patung-patung kerajaan Singosari dan Majapahit ketika diketemukan sudah diwujudkan dengan mengenakan kain batik sebagai busana istana.

Sesuai dengan lingkungan seni zaman Hindu seni batik merupakan karya seni istana dengan pembakuan tradisi yang diteruskan pada zaman Islam. Hasil yang telah dicapai zaman Hindu baik dari segi teknik membatik maupun estetik diteruskan hingga zaman Islam dengan dipengaruhi unsur-unsur baru. Pada zaman Hindu desain hiasan batik diperkaya dengan motif-motif baru selain pengembangan dan penyempurnaan berbagai motif geometris dan motif tumbuhtumbuhan.

\section{Batik Tradisional/Classical Batik}

Dalam buku "Seni Kerajinan Btik Indonesia" (Susanto, Sewan:1980), disebutkan bahwa berdasarkan susunan bentuk ornamen di dalam motif batik maka motif-motif batik digolongkan dalam 5 kelompok, yaitu: Motif Banji (motif Geometris), Motif Semen (Motif Ganggong), Motif Ceplokan, Motif
Anyaman, dan Motif Parang dan Lereng. Lebih lanjutSamsiSudewi(2011), dalambuku "Batik From the Court Java and Sumatra, menampilkan contoh motif geometris dalam bentuk gambar dan nama motif "semen": sesuai dengan kelompok-kelompok jenis motifnya. Motif ceplok ditampilkan dalam 76 gambar yang terbagi dalam; semen 3 (tiga kelompok. Yaitu; (a) semen tumbuhtumbuhan (bunga, kuncup; dan daun); (b) semen tumbuh-tumbuhan dan binatang; dan (c) Semen tumbuhan dan binatang bersayap (lar-laran). Kecuali motif ceplok Sudewi juga menggambarkan motif kawung dalam 23 jenis motif kawung. Diantaranya kawung picis, kawung sen, kawung sawo kecik, kawung sawo pecah, kawung mangurat, kawung putrid dan lain-lain. Kecuali motif kawung, motif batik tradisional juga terdapat motif lain yaitu moyif parang dan motif lereng. Motif parang terdiri dari 60 mjenis motif, diantaranya motif parang baladewa, parang rusak, parang basuki, parang curigo, parang gunung paying, parang harjono dan lain-lain. Motif lereng terdiri dari 20 motif diantaranya; lereng dono tirto, lereng bangun ningrat, lereng blambangan, lereng candi puro, lereng golang galling, lereng kembang barem, lereng modang, lereng udan tritis, lereng danatirta dan lain lain. Kecuali itu dalam motif batik tradisional juga terdapat motif lung-lungan dan motif semen. Motif lung-lungan diantaranya; lung-lungan anggur, babon angrem, cendrawasih, cuwiri solo, gabah sinawur, gajah birowo dan lain lain. Motif lung-lungan dan semen terdiri dari 60 jenis motif. Kecuali terdiri dari motif tumbuh-tumbuhan (buah, daun dan bunga) batik tradisional juga terdapat motif wayang, diantaranyas; motif pandowo limo ( Punto Dewo, arjuno, werkudoro, nakula, sadewa0, juga ponokawan (Petruk, Semar, Bagong) dan lain-lain. Motif wayang ditampilkan dalam 40 motif.

\section{Golongan Motif Geometris}

Motif geometris merupakan salah satu motif 
yang paling tua digunakan karena sudah ada sejak zaman prasejarah. Dalam aplikasinya, motif geometris mengembangkan unsurunsur seni rupa seperti titik, garis, bidang. Yang termasuk dalam golongan Geometris adalah: motif banji, motif gangnggong, motif anyaman, motif parang dan lereng (Susanto, Sewan: 1980. P. 213). Ragam hias geometris terbagi kedalam tiga jenis, yaitu: ragam hias yang dipakai untuk menghias bagian tepi atau pingiran dari suatu benda, motif hias geometris yang diterapkan sebagai pengisian dari bagian benda pakai, dalam hal ini pada permkaan bidangnya, ragam hias geometris sebagai inti atau bagian yang berdiri sendiri dan merupakan unsur estetik, dalam bentuk ornamen arsitektural (Toekio, Soegeng: 2000. P.38)

Motif geometris sering disebut motif ilmu ukur karena motif batik ini memiliki gambar yang berulang serta motifnya merupakan bentuk bidang simetris. Motif geometris cenderung memiliki kesan luwes karena dapat diterapkan pada berbagai macam benda, tanpa terlihat seperti dipaksakan namun mampu menimbulkan kesan indah. Motif batik geometris nusantara meliputi: Swastika, Banji, pilin atau spiral, Meander, Kawung, Tumpal, Ceplokan.

\section{Pengertian Makna Simbolis}

Batik merupakan seni tradisional. Setiap batik memiliki latar belakang, arti perlambangan atau makna simbolis yang menjadi dasar penciptaan batik tersebut sehingga tatanan warna, pola maupun motif pada batik tidak bisa sembarangan di ubah. Bahkan suatu budaya diciptakan selalu tanpa terlepas dari sebuah makna. Umumnya makna budaya tersebut diciptakan dengan menggunakan simbol-simbol. Dilihat dari pengertian simbol secara umum, simbol mencakup berbagai aspek yang luas. Karena apabila berbicara mengenai simbol, otomatis juga akan berbicara mengenai semiotika.

Piliang (2009:11) menyatakan bahwa "semiotika adalah ilmu yang mempelajari tanda (sign), berfungsinya tanda, dan produksi makna. Tanda adalah sesuatu yang bagi seseorang berarti sesuatu yang lain. Tanda tidak hanya berbentuk sebuah benda". Tanda dalam kehidupan manusia selalu menyampaikan suatu informasi sehingga mempunyai sifat komunikatif. Merujuk teori Pierce dalam Piliang (2009:16), bahwa tanda-tanda dalam gambar dapat digolongkan ke dalam ikon, indeks, dan simbol. Ikon adalah tanda yang mirip dengan objek yang diwakilinya. Dapat pula dikatakan, ikon adalah tanda yang memiliki ciri-ciri yang sama dengan apa yang dimaksudkan. Indeks merupakan tanda yang memilik hubungan sebab-akibat dengan apa yang diwakilinya atau disebut juga tanda sebagai bukti. Simbol merupakan tanda berdasarkan konvensi, peraturan, atau perjanjian yang disepakati bersama. Simbol baru dapat dipahami jika seseorang sudah mengerti arti yang telah disepakati sebelumnya.

Makna simbolis yang terkandung dalam tiap motif batik di berbagai daerah biasanya diartikan secara kultural menurut keyakinan, kebiasaan atau tradisi, serta cara hidup dari masyarakatnya yang sampai sekarang tetap bertahan. Dalam membuat sebuah motif batik, pengrajin akan menggunakan dasardasar yang diyakini oleh masyarakat untuk dijadikan sebuah makna. Sehingga masingmasing motif batik ditafsirkan sesuai dengan makna yang hidup dimasyarakat.

Pemahaman terhadap simbol dapat diidentifikasi sebagai kata benda, kata kerja dan kata sifat. Simbol sebagai kata benda dapat berupa barang, obyek, tindakan dan halhal konkret lain. Simbol sebagai kata kerja dapat berfungsi sebagai menggambarkan, menyelubungi, mengartikan, menunjukkan, memanipulasi, dan menandai. Simbol sebagai kata sifat berarti sesuatu yang lebih besar, lebih bermakna, lebih bernilai, sebuah kepercayaan, dan prestasi. Fungsi simbol digunakan untuk menjembatani obyek atau 
hal-hal yang nyata dengan hal-hal yang abstrak yang maknanya melebihi dari makna hal yang tampak. Menurut Musman dan Arini (2011:7) bahwa "simbol adalah kreasi manusia untuk mengejawantahkan ekspresi dan gejala-gejala alam dengan bentuk-bentuk bermakna, yang artinya dapat dipahami dan disetujui oleh masyarakat tertentu".

\section{Semiotika Dekonstruktif}

Dekonstruksi adalah istilah yang digunakan oleh Jaques Derrida sebagai salah satu bentuk pembongkaran terhadap oposisi binner seperti ucapan/tulisan. Derrida berpendapat bahwa tulisan sebagai alternative dalam berpikir bahasa, dengan melepaskan diri dari ketergantungan pada ucapan/logos, tulisan bisa menjadi sebuah permainan bebas unsur-unsur dalam bahasa dan komunikasi. Istilah penting lainnya dalam dekonstruksi adalah diseminasi. Diseminasi adalah keadaan kehampaan makna disebabkan telah dibongkarnya petanda/logos. Dengan membongkar petanda makna maka lenyap pula fungsi komunikasi dari bahasa. Dalam ketiadaan petanda/logos maka bahasa berkembang lewat energy dan kreativitasnya sendiri (Levin, David Michel, 1988:5)

Dalam deseminasi system bahasa yang telah dibongkar atau didekonstruksi, berubah menjadi suatu penjelajahan anarkhis melalui ungkapan bahasa. Bahasa menjadi sebentuk subversi dan parodi terhadap semua maknamakna yang dianggap mapan pada tingkat kontrol sosial biasa. Dengan demikian dekonstruksi yang telah mampu membongkar pandangan dominan dalam semiotika (tanda, makna, konsep) tak dapat lagi memfungsikan bahasa sebagai wacana sosial, yaitu wacana komunikasi bermakna diantara subyeksubyek (Baudrillard, Jean. 1990:25).

Semiotika sudah dikenal sejak jaman Yunani karena semiotik berasal dari bahasa Yunani yaitu semion yang berarti tanda. Pada awal abad 20 Ferdinand de Saussure mengangkat kembali ilmu semiotika hingga era konsumerisme dewasa ini semiotika bahkan menjadi ilmu kunci dalam berbagai bidang kajian. Seperti dalam bidang kebudayaan, studi sosial, studi media, film, fashion, seni, dan barang consumer misalnya. Dalam semiotika satu kata memiliki makna tertentu di sebabkan adanya kesepakatan sosial di antara komunitas pengguna bahasa tentang makna tersebut (Culler; 1976, p. 19).

Setidak-tidaknya ada dua kondisi yang melatarbelakangi perbincangan mengenai tanda di dalam masyarakat consumer. Yasraf Amir Piliang, berpendapat; Pertama, perbincangan mengenai tanda dan semiotika pada umumnya terpusat pada peranan pentingnya dalam arena komunikasi melalui komoditi pada masyarakat consumer. Sehingga seolah-olah fenomena semiotika hanya terdapat pada wacana komoditi tersebut (iklan, televise, fashion). Kedua, sesungguhnya media menjadi sebuah arena perjuangan bagi eksistensi tanda-tanda, dan demikianjuga arena perjuangan bagiidentitasidentitas. Tanda dan identitas diperjuangkan atas dasar kepentingan berbeda-beda yang ada pada masyarakat; kepentingan ekonomi, politik, budaya, agama. Di dalam masyarakat consumer dewasa ini makna-makna yang kedua banyak diwarnai oleh sifat-sifat glamour, dangkal, material, fulgar, anarkis, immoral, transparan lebih banyak menjajah di sudut-sudut kehidupan (Piliang, 1999,p. 262).

Yulia Kristeva melalui semiotika revolosionernya mengembangkan kemungkinan bentuk pelanggaran, subversi dan kreatifitas anti sosial dalam bahasa. Seperti halnya Derrida; Kristeva menjadikan semiotika structural Saussure sebagai obyek subversi dan pembongkaran, Kristeva melihat semiotika Saussurean sebagai obyek satu wacana yang hanya menawarkan makna tunggal, disebabkan ia dalam menjelajahi ruang epistemologisnya, menolak hadirnya subyek sebagai agen perubahan dan subversi bahasa (Kristeva, Julia; 1980,p.127).

Semiotik dalam pandangan postrukturalis tidak lagi menaruh perhatian pada system tanda-tanda, melainkan dengan pembentukan subyek serta peranannya dalam perubahan bahasa. Bagi pemikir postrukturalis, bahasa tidak lagi semata system pembedaan 
(difference) akan tetapi jejak (defferance); penanda dan petanda tidak lagi satu kesatuan bagai dua sisi dari selembar kertas, melainkan terpisah; petanda tidak begitu saja hadir, melainkania selalu didekonstruksi, hubungan antara penanda dan petanda tidak lagi bersifat simetris dan stabil berdasarkan konvensi, akan tetapi terbuka bagi permainan bebas penanda (Piliang; 1980,p.266).

Jaques Derrida memandang kecenderungan Saussure dalam konsep bahasanya untuk bergantung pada referensi makna yang mendahului petanda sebagai satu kecenderungan dogmatis dan tidak kreatif dalam wacana bahasa, karena menutup peluang-peluang bagi penafsiran baru. Derrida membedakan antara dua pandangan tentang tafsiran. Pertama, yang disebutnya tafsiran retrospektif, yaitu upaya-upaya bagi rekonstruksi makna atau kebenaran asli atau awal; Kedua, tafsiran prospektif yang secara eksplisit menerima ketidakpastian makna (Sturock, John: 1979, p158). Tafsiran pertama membentuk ketergantungan pada logos, yaitu yang di dalam filsafat disebut kebenaran mutlak, ia dapat diterjemahkan sebagai wahyu Tuhan sebagai fondasi dari segala wacana dalam kehidupan manusia.

Derida membangun teori semiotikanya yang bertolak belakang dengan teori Husserl ; "Meaning thus understood is not just meaning in the sense that words mean, but in the sence that someone means them to mean"(Hartland: 1987, p.126). bagi Derrida bahasa bersifat memenuhi dirinya sendiri (self sufficient) dan bahkan terbebas dari manusia. Derrida melihat bahasa bersumber dari tulisan manusia, menurutnya tulisan adalah bahasa yang secara maksimal memenuhi dirinya sendiri karena tulisan memenuhi ruang secara maksimal pula. Sebagai bahasa, tulisan tidak terdapat di dalam pikiran manusia atau di dalam gelombang udara, tetapi konkrit di atas halaman. Tulisan terlepas dari penulisnya begitu berada di ruang halaman, sedangkan ketika dibaca tulisan langsung berkaitan dan terbuka untuk difahami pembacanya. Jadi bahasa yang sebenarnya adalah tulisan, bukan suara. Tidak demikian halnya dengan pendapat Huserl. Ia menempatkan sumber bahasa pada manusia penghasilnya. Bagi Huserl sumber bahasa adalah "suara"(voix/ voice). Hood, Benny H.(2014:27).

Bagian lain dari teori yang disusun Derrida adalah tentang tanda bahasa dan pemaknaannya. Derrida menolak pemikiran tentang tanda yang selama ini dipandang seakan-akan berlangsung secara murni dan sederhana. Bagi Derrida pemaknaan mengenai hal yang dimaknai adalah suatu proses dengan cara membongkar dan menganalisis secara kritis (critical analysis) hal yang dimaknai. Bagi Derrida hubungan penanda dan petanda tidak bersifat tetap, tetapi pada kenyataannya dapat 'ditunda' untuk memperoleh hubungan yang lain atau baru. Oleh karena itu, makna suatu tanda diperoleh tidak berdasarkan pembedaan antar tanda yang hubungan antar penandapetandanya bersifat tetap (statis), tetapi dapat berubah-ubah sesuai dengan kehendak pemakai tanda. Apa yang terjadi dalam proses pemahaman makna tanda bukan sekedar karena ada proses "penundaan", hubungan antara penanda (bentuk tanda) dan petanda (makna tanda) untuk menemukan makna lain atau makna baru. Proses tersebut dikenal sebagai proses dekonstruksi (Hood, Benny H.(2014:28).

Hubungan antara petanda-penanda disebutnya defferance. Kata ini hanya untuk menunjukkan makna tanda bersifat dinamis sebagai hasil proses dekonstruksi. Konsep defferance merupakan dasar bagi eksistensi sebuah tanda, tetapi selanjutnya tanda tersebut harus difahami dalam waktu dan situasi yang berbeda-beda sehingga kemudian akan terlihat maknanya. Jadi makna tanda tidak hanya terjadi dalam satu kali, tetapi pada waktu dan situasi yang berbeda-beda dengan makna yang berbeda-beda pula. Dari uraian tersebut dapat dikatakan bahwa teori yang dikemukakan Derrida termasuk dalam ranah semiotik.

Apakah konsep Derrida dapat diterapkan pada teks bukan sastra? Justru jika pemikiran Derrida diterapkan secara konsisten dapat diaplikasikan pada setiap jenis teks meskipun 
bukan sastra. Teks yang dimaksud dalam konteks ini termasuk: teks iklan, tulisan sejarah, prasasti, arsip, teks politik, teks keagamaan, polemic, khotbah, dan pidato termasuk pada teks visual seperti; lukisan/ gambar, iklan, film lebih peka terhadap proses pemaknaan secara dekonstruksi. Sehubungan dengan penelitian ini kajian terhadap berbagai motif batik termasuk dalam ranah teks visual.

\section{Pembahasan}

Melestarikan Warisan Budaya Tak Benda (batik) merupakan salah satu upaya bagi bangsa Indonesia khususnya bagi para generasi penerus agar kekayaan budaya yang di miliki tidak akan punah. Indonesia yang memiliki beragam kebudayaan sudah patut untuk mestarikannya. Seperti yang telah diketahui bahwa pada tanggal 2 Oktober 2009, UNESCO salah satu badan PBB yang menangani bagian pendidikan dan kebudayaan telah mengukuhkan bahwa batik adalah Warisan Budaya Dunia Tak Benda yang Berasal Asli dari Indonesia.

Mengapa batik disebut warisan budaya dunia tak benda? karena dalam hal ini yang diwariskan bukanlah benda batiknya, akan tetapi prosesnya maka dari itu batik disebut sebagai warisan budaya dunia tak benda. Sebelumnya badan UNESCO telah mengadakan penelitian tentang asal usul batik. Pertama, mereka bertanya pada pembatik yang berada di Malaysia. Sudah berapa lama membatik, mereka menjawab sudah 9 tahun. Kedua, UNESCO memberikan pertanyaan yang sama pada pembatik Jawa dan beliau menjawab baru 3 tahun. Lalu ditanya lagi, belajar membatik di mana? beliau menjawab dari ibunya, ibunya di tanya lagi dan menjawab dari ibu saya, terus hingga sampai ke eyang buyut beliau. sedangkan pembatik yang ada di Malaysia menjawab beliau belajar dari orang Jawa yang termasuk wilayah Indonesia. Dengan begitu, batik merupakan asli dari Indonesia.

\section{Batik Keraton}

Batik keraton ('bentuk teks' Keraton Kasepuhan dan Keraton Kanoman) pada awalnya merupakan hasil kecintaan keluarga keraton pada seni lukis. Dahulu sebelum ada katun, hasil lukisan masih menggunakan daun lontar sebagai kanvasnya. Hasil lukisan pada media daun lontar kemudian dibawa keluar oleh para abdi dalem. Seiring berjalannya waktu, batik Cirebon mengalami perkembangan, media gambar tidak lagi menggunakan daun lontar, melainkan menggunakan katun (kain).

Motif Batik Cirebon yang paling terkenal adalah motif Mega Mendung. Berbentuk gumpalan-gumpalan awan putih yang mengumpul. Motif Mega Mendung juga bermakna kehidupan dunia atas, atau bisa bermakna kebebasan. Batik yang berasal dari keraton memiliki warna yang cederung gelap. Pemakaian warna seperti hitam, merah tua, coklat menjadi warna yang mendominasi. Ciri ini yang kemudian membedakan batik Keraton dengan batik daerah pesisir. Batik daerah pesisir memiliki warna dasar yang cerah, seperti biru, hijau, dan merah. Tidak demikian halnya dengan batik pesisir atau Trusmi menggunakan motif yang berhubungan dengan keadaan sekitar, seperti motif udang, ikan, dan bunga.

Motif batik Cirebon yang berkembang erat kaitannya dengan simbol-simbol kosmologi, misalnya motif Taman Arum Sunyaragi, Wadas Singa, Patran Kangkung, Wadas Mantingan, Ayam Alas, Supit Udang atau motif yang selalu dihubungkan dengan Batik Cirebon adalah motif Mega Mendung.

Motif Batik Taman Arum Sunyaragi di dalamnya terkandung makna kearifan kehidupan sosial lokal khususnya di lingkungan Kasultanan Cirebon. Ornamenornamen yang tergambar di dalamnya membawa simbolisasi tradisi kreatif sekaligus spiritual dari Keluarga Sultan. Taman (sunyaragi) memiliki arti khusus bagi keluarga Keraton Cirebon saat itu. Sementara itu Motif Wadasan (wadas=cadas, batu karang) menyimbolkan makna kekuatan dan keteguhan. Motif ini sering disandingkan dengan 'mega mendung', keduanya merupakan ornamen Batik Cirebon yang mengadopsi ornamen-ornamen yang banyak 
terdapat pada barang-barang karya seni yang dibawa dari Tiongkok. Berbagai unsur budaya, seni yang dibawa para 'saudagar' tersebut memberi warna baru dan melahirkan konsep Batik Pesisir, sebagaimana dapat dilihat pada batik Cirebon, termasuk batik yang dihasilkan daerah pesisir pantai Jawa lainnya (Pekalongan, Lasem, Tuban dsb). Contohnya motif Nagasebho (Naga yang sedang menghadap raja).

Dalam beberapa referensi disebutkan bahwa motif-motif 'adaptasi' (dari budaya asing) tersebut berawal dari pesanan dari para sudagar dari tanah seberang, yang kemudian diminati juga oleh kalangan keraton, dan diapresiasi dengan pemakaian ornamenornamen (motif) resapan ini sebagai bagian batik keraton. Akulturasi budaya (salah satunya terekam dalam motif batik) ini diperkuat dengan pernikahan Sultan Cirebon (Sunan Gunung Jati) dengan putri Tiongkok, bernama Ong Tien Nio, dari negeri Tar Tar.

Secara umum, ragam hias batik keraton Cirebon dibagi menjadi dua jenis. Yaitu: pertama, jenis motif yang biasa digunakan oleh raja dan kerabatnya (ningrat) dengan ragam hias halus dengan motif rinci. Jenis kedua, untuk motif yang dikenakan oleh para abdi dalem dengan ragam hias batik besar dan kuat.

\section{Motif Batik Cirebonan}

Masuknya Belanda ke Indonesia kemudian secara tidak langsung membawa perubahan pada peran dan fungsi batik dilingkungan keraton secara umum, termasuk pada Keraton Cirebon. Batik Keraton mulai bebas dipakai oleh kalangan biasa tanpa batasan/larangan pada penggunaan jenis motif tertentu. Ini diperkuat dengan semakin kentalnya nilai religius khususnya Islam dalam masyarakat, dimana dalam Islam tidak dikenal pembedaan kelas di dalam masyarakat. Warisan Batik Keraton Cirebon ini, sampai saat ini masih diproduksi (secara turun-temurun) dan untuk Batik Cirebon ini satu-satunya daerah yang dikenal sebagai sentra batik adalah daerah Trusmi.

Begitu dalamnya orang Jawa memberi makna pada busana bahwa: “...ajining diri gumantung ono ing lati, ajining jiwo gumantung ono ing busano" Harga diri terletak dari kualitas bicara seseorang demikian juga penampilan dan cara berbusana akan memberi nilai terhadap kualitas jiwa seseorang. Busana adalah cerminan identitas, watak, dan kondisi sosial ekonomi pemakainya, juga merupakan indikator moral dan budaya suatu bangsa. Bagi mayoritas masyarakat Cirebon yang beragama Islam, busana selain alat pelindung tubuh yang vital (penutup aurat), juga harus bernilai keindahan dan kesopanan. Kain batik adalah salah satu busana tradisional Cirebon yang menjadi komoditas industri seiring dengan meningkatnya ekonomi masyarakat di akhir Abad 19 hingga awal abad 20-an.

Batik Cirebon diproduksi dibeberapa tempat baik dalam kota maupun luar kota Cirebon. Didalam kota Cirebon batik diproduksi di lingkungan keraton Kasepuhan, keraton Kanoman, dan keraton Kacirebonan, Kaprabonan, serta kampung Kanduruan yang mayoritas penduduknya etnis Cina. Sedangkan diluar kota Cirebon terdapat para pengrajin batik seperti di daerah Plumbon, Trusmi, Plered, Kalitengah, dan Battembat. Pengrajin batik juga terdapat di daerah Paoman Indramayu dan Cigugur Kuningan. Kini sentra industri Batik Cirebon yang masih bertahan dipusatkan di desa Trusmi Kabupaten Cirebon, sehingga masyarakat menganggap bahwa Batik Cirebon identik dengan "Batik Trusmi". Motif batik Cirebon yang populer diantaranya motif "Wadasan" dan "Mega Mendung".

Batik Trusmi berhasil menjadi ikon batik dalam koleksi kain nasional. Batik Cirebon sendiri termasuk golongan Batik Pesisir, namun juga sebagian batik Cirebon termasuk dalam kelompok batik keraton. Hal ini dikarenakan Cirebon memiliki tiga buah keraton yaitu Keraton Kasepuhan dan Keraton Kanoman, ketiga keraton Kacirebonan, yang konon berdasarkan sejarah dari tiga keraton ini muncul beberapa desain batik Cirebonan Klasik yang hingga sekarang masih dikerjakan oleh sebagian 
masyarakat desa Trusmi diantaranya seperti motif Mega Mendung, Paksi Naga Liman, Patran Keris, Patran Kangkung, Singa Payung, Singa Barong, Banjar Balong, Ayam Alas, Sawat Penganten, Katewono, Gunung Giwur, Simbar Menjangan, Simbar Kendo dan lain-lain

Beberapa hal penting yang bisa dijadikan keunggulan atau juga merupakan ciri khas yang dimiliki oleh batik Cirebon adalah sbb: (a) Desain batik Cirebonan yang bernuansa klasik tradisional pada umumnya selalu mengikut sertakan motif wadasan (batu cadas) pada bagian-bagian motif tertentu. Disamping itu terdapat pula unsur ragam hias berbentuk awan (mega) pada bagian-bagian yang disesuaikan dengan motif utamanya; (b) Batik Cirebonan klasik tradisional selalu bercirikan memiliki warna pada bagian latar (dasar kain) lebih muda dibandingkan dengan warna garis pada motif utamanya; dan (c) Bagian latar atau dasar kain biasanya nampak bersih dari noda hitam atau warnawarna yang tidak dikehendaki pada proses pembuatan. Noda dan warna hitam bisa diakibatkan oleh penggunaan lilin batik yang pecah, sehingga pada proses pewarnaan zat warna yang tidak dikehendaki meresap pada kain.

Perkembangan pada masa sekarang, pewarnaan yang dimiliki oleh batik Cirebonan lebih beraneka warna dan menggunakan unsur-unsur warna yang lebih terang dan cerah, serta memiliki bentuk ragam hias yang bebas dengan memadukan unsur binatang dan bentuk-bentuk flora yang beraneka rupa.

Produksi batik Cirebonan pada masa sekarang terdiri dari batik Tulis, batik Cap dan batik kombinasi tulis cap. Pada tahun 1990 - 2000 ada sebagian masyarakat pengrajin batik Cirebonan yang memproduksi kain bermotif batik Cirebonan dengan teknik sablon tangan (hand printing), namun belakangan ini teknik sablon tangan hampir punah, dikarenakan kalah bersaing dengan teknik sablon mesin yang dimiliki oleh perusahaan-perusahaan yang lebih besar.
PertumbuhanbatikTrusmimenurutresponden bergerak dengan cepat mulai tahun 2000, hal ini bisa dilihat dari bermunculan showroomshowroom batik yang berada di sekitar jalan utama desa Trusmi dan Panembahan. Pemilik showroom batik Trusmi hampir seluruhnya dimiliki oleh masyarakat Trusmi asli walaupun ada satu atau dua saja yang dimiliki oleh pemilik modal dari luar Trusmi.

\section{Motif Batik Cirebon (Pesisiran)}

Berkurangnya nilai-nilai perlambangan sejalan dengan berkurangnya nilai seni batik yang dituntut oleh tradisi 'kebudayaan baru'. Nilai baru yang ikut berperan dalam perkembangan seni batik sebagai seni klasik ialah nilai ekonomi Batik tidak lagi semata-mata sebagai pakaian upacara atau benda pusaka istana. Batik dalam perkembangannya menjadi jenis pakaian sehari-hari yang meluas dalam masyarakat biasa. Dari hal tersebut timbulah kebutuhan untuk menghasilkan batik yang berlipat ganda dalam produksinya. Kebutuhan ini menghasilkan cara baru dalam pengadaan batik, baik dari teknik maupun manajemen pemasarannya. Dari segi teknik pengadaan batik sudah tidak lagi menggunakan teknik tulis tetapi dengan menggunakan cap walaupun cap tidak bisa menggantikan batik tulis. Pola pemasaran juga sudah berubah dari getok tular pemesanan menjadi manajemen modern.

Motif batik "Wadasan" dan "Mega Mendung" merupakan motif batik Cirebon yang sangat populer saat ini bahkan menjadi ikon "Batik Cirebonan" yang dikenal hingga mancanegara. Motif tersebut baru muncul secara bebas dalam pasaran perbatikan Cirebon dimulai pada era tahun 1970-an. Sebelumnya motif Wadasan dan Megamendung adalah motif batik Keraton Cirebon yang bersifat "Sakral". Sepanjang penelitian penulis berdasarkan foto-foto lama pakaian para bangsawan Keraton Cirebon di era tahun 1930-1940-an tidak diketemukan kedua motif batik tersebut dipakai oleh para bangsawan Keraton Cirebon saat itu. Motif batik "Wadasan" berasal dari kata Wadas masyarakat Cirebon memaknainya 
"Tanah yang sangat keras" atau "Batu Cadas". Inspirasi motif Wadasan didapat dari panorama alam Cirebon sebagai negeri pesisir yang banyak dijumpai "Batu Cadas" atau "Batu Karang" di pantai yang tegar menahan gempuran ombak lautan. Motif Wadasan selalu digunakan untuk motif hias batik "Keratonan" Cirebon. Motif ini selain sebagai hiasan pembantu juga digunakan pula sebagai pokok hiasan. Motif batik yang menggunakan pokok hiasan Wadasan adalah motif "Rajeg Wesi", "Wadas Grompol", dan "Panji Sumirang".

Motif batik "Mega Mendung" merupakan visualisasi dari bentuk "Mega" atau "Awan", motif ini merupakan pengaruh kebudayaan Cina yang merambah ke Cirebon, salah satu buktinya terdapat pada lukisan-lukisan awan pada piring Cina yang menempel pada tembok bangunan Situs Makam Sunan Gunung Jati. Bentuk awan diolah sedemikian rupa oleh para seniman dengan gaya tersendiri dengan bentuk awan yang berlapis-lapis dengan warna merayang hingga tegas.

Bagi masyarakat Cirebon yang mayoritas beragama Islam "Motif Wadasan" memiliki filosofi bahwa dasar agama, keimanan seseorang atau "Aqidah" harus "Kokoh" seperti batu cadas, kuat dan tidak goyah dan selalu istiqomah dalam menghadapi godaan maupun rintangan. Kokohnya keimanan tersebut seraya mengharap turunnya keberkahan, dan naungan dari dzat "Yang Maha Kuasa" yang disimbolkan dengan "Mega Mendung". Mega Mendung juga merupakan simbol akan datangnya pertolongan dan rezeki berupa "Hujan" yang akan menyuburkan tanaman dan binatang ternak serta memberikan rezeki pada para petani. Lapisan-lapisan warna tegas pada motif "Mega Mendung" menyimbolkan pula tingkatan-tingkatan keimanan dan ketaqwaan seorang muslim, serta lapisanlapisan kehidupan di jagat raya atau alam semesta.

Raenide (pembatik berusia 66 tahun) menuturkan Cirebon kaya dengan motif batik yang unik, "Ini motif Kembang Arang, batik yang berbunga namun tidak banyak" katanya, sambil menunjukkan kain batik tulis berwarna-warni hasil buatan tangannya. Singo Barong, adalah batik dengan motif bergambar Singa. Dan motif-motif seperti Patran, Kereta Kencana, Seribu Sono, Sawat Pengantin, Naga Seba, Taman Arum, Gresikan, Banjar Balong, dan lain-lain lagi. Satu lembar kain batik, pengerjaannya membutuhkan waktu yang berbeda-beda, tergantung tingkat kesulitan motif yang dibuat, untuk motif Kembang Arang cukup satu hari dapat diselesaikan, berbeda dengan Sawat Pengantin bisa menghabiskan waktu tiga bulan lamanya untuk menyelesaikan seluruh proses membatik.

\section{KESIMPULAN}

Ragam Hias Keraton, benda kuno keraton yang menunjukkan dengan jelas perpaduan unsur berbagai agama dan budaya adalah kereta kencana Singa Barong (kereta kencana tua canggih pertama buatan Indonesia pada masanya). Ragam hias dari ketiga agama juga di tampilkan pada seluruh fisik kereta singo barong, ragam hias mega mendung, wadasan, pandan wangi, naga, burung, dan lain-lain. Motif mega mendung ragam karya cipta kanjeng Sunan Gunung jati merupakan perlambangan dunia atas bahwa sebagai umat manusia agar senantiasa selalu eling dan waspodo. Ragam hias pada fisik kereta yang tiga dimensi ini hampir secara keseluruhan telah didekonstruksikan menjadi karya seni dua dimensi yaitu motif batik keraton. Ragam hias Kereta singo barong didekonstruksi menjadi karya dua dimensi yaitu motif batik singo barong, motif mega mendung pada ukiran bodi kereta dituangkan ke dalam karya batik motif mega mendung. Demikian juga ragam hias wadasan, pandan wangi, burung dan lain-lain juga di gunakan sebagai motif batik keraton Cirebon. Pendekonstruksian ini tidak berpengaruh pada makna simbolik baik ragam hias keraton maupun motif batik keraton. Umumnya batik yang berasal dari keraton memiliki warna yang cederung gelap. Pemakaian warna seperti hitam, merah tua, coklat menjadi warna yang mendominasi. Ciri ini yang kemudian 
membedakan batik Keraton dengan batik daerah pesisir. Batik daerah pesisir memiliki warna dasar yang cerah, seperti biru, hijau, dan merah. Tidak demikian halnya dengan batik pesisir atau Trusmi menggunakan motif yang berhubungan dengan keadaan sekitar, seperti motif udang, ikan, dan bunga. Batik pada masa pemerintahan Kesultanan Cirebon pada awalnya diperuntukkan bagi raja dan keluarganya. Sebagai sebuah Kesultanan Islam, batik saat itu juga erat kaitannya dengan upacara-upacara keagamaan, penolak bala dan sebagainya.

\section{Batik Keraton}

Motif batik Cirebon yang berkembang pada saat itu erat kaitannya dengan simbol-simbol kosmologi. Motif Wadasan menyimbolkan makna kekuatan dan keteguhan, motif ini sering disandingkan dengan 'mega mendung', keduanya merupakan ornamen batik Cirebon yang mengadopsi ornamenornamen yang banyak terdapat pada barangbarang karya seni yang dibawa dari Tiongkok. Berbagai unsur budaya, seni yang dibawa para 'saudagar' tersebut memberi warna baru dan melahirkan konsep Batik Pesisir, sebagaimana dapat dilihat pada batik Cirebon, termasuk batik yang dihasilkan daerah pesisir pantai Jawa lainnya (Pekalongan, Lasem, Tuban dsb). Secara umum, ragam hias batik keraton cirebon (dalam pengenaannya) dibagi menjadi dua jenis. Yaitu: pertama, jenis motif yang biasa digunakan oleh raja dan kerabatnya (ningrat) dengan ragam hias halus dengan motif rinci. Jenis kedua, untuk motif yang dikenakan oleh para abdi dalem dengan ragam hias batik besar dan kuat.

\section{Motif Batik Cirebonan}

Kain batik adalah salah satu busana tradisional Cirebon yang menjadi komoditas industri seiring dengan meningkatnya ekonomi masyarakat di akhir Abad 19 hinngga awal abad 20. Saat itu Batik Cirebon diproduksi dibeberapa tempat baik dalam kota maupun luar kota Cirebon. Didalam kota Cirebon batik diproduksi di lingkungan keraton Kasepuhan, keraton Kanoman, dan keraton Kacirebonan, Kaprabonan, serta kampung
Kanduruan yang mayoritas penduduknya etnis Cina. Sedangkan diluar kota Cirebon terdapat para pengrajin batik seperti di daerah Plumbon, Trusmi, Plered, Kalitengah, dan Battembat. Pengrajin batik juga terdapat di daerah Paoman Indramayu dan Cigugur Kuningan. Kini sentra industri Batik Cirebon yang masih bertahan dipusatkan di desa Trusmi Kabupaten Cirebon, sehingga masyarakat menganggap bahwa Batik Cirebon identik dengan "Batik Trusmi".

Daerah sentra produksi batik Cirebon kini berada di desa Trusmi Plered Cirebon yang terletak di luar Kota Cirebon sejauh $4 \mathrm{~km}$ menuju arah barat atau menuju arah Bandung. Batik Trusmi berhasil menjadi ikon batik dalam koleksi kain nasional. Batik Cirebon sendiri termasuk golongan Batik Pesisir, namun juga sebagian batik Cirebon termasuk dalam kelompok batik keraton. Hal ini dikarenakan Cirebon memiliki tiga buah keraton yaitu Keraton Kasepuhan dan Keraton Kanoman, ketiga keraton Kacirebonan, yang konon berdasarkan sejarah dari tiga keraton ini muncul beberapa desain batik Cirebonan Klasik yang hingga sekarang masih dikerjakan oleh sebagian masyarakat desa Trusmi diantaranya seperti motif Mega Mendung, Paksi Naga Liman, Patran Keris, Patran Kangkung, Singa Payung, Singa Barong, Banjar Balong, Ayam Alas, Sawat Penganten, Katewono, Gunung Giwur, Simbar Menjangan, Simbar Kendo dan lain-lain.

\section{Motif Batik Cirebon (Pesisiran)}

Batik Cirebonan mempunyai ciri yang berbeda dengan kelompok batik cirebon pesisiran. Batik Cirebon Pesisiran sangat dipengaruhi oleh karakter masyarakat pesisiran yang pada umumnya memiliki jiwa terbuka dan mudah menerima pengaruh budaya asing. Pada daerah sekitar pelabuhan biasanya banyak orang asing yang singgah, berlabuh hingga terjadi perkawinan etnis yang berbeda (asimilasi), maka batik Cirebonan Pesisiran lebih cenderung menerima pengaruh budaya dari luar yang dibawa oleh pendatang. Motif batik Cirebon (batik Pesisiran) cenderung menggunakan ragam 
hias yang tidak menimbulkan syirik yaitu tidak mensekutukan Tuhan.: Motif Kaligrafi, Motif geometris, stilasi flora, stilasi flora dan fauna, pemandangan alam. Motif batik "Mega Mendung" merupakan visualisasi dari bentuk "Mega" atau "Awan", motif ini merupakan pengaruh kebudayaan Cina yang merambah ke Cirebon. Bentuk awan diolah sedemikian rupa oleh para seniman dengan gaya tersendiri dengan bentuk awan yang berlapis-lapis. Bagi masyarakat Cirebon yang mayoritas beragama Islam "Motif Wadasan" memiliki filosofi bahwa dasar agama, keimanan seseorang atau "Aqidah" harus "Kokoh" seperti batu cadas, kuat dan tidak goyah dan selalu istiqomah dalam menghadapi godaan maupun rintangan. Kokohnya keimanan tersebut seraya mengharap turunnya keberkahan, dan naungan dari dzat "Yang Maha Kuasa" yang disimbolkan dengan "Mega Mendung".

\section{DAFTAR PUSTAKA}

Alwasilah, A. Chaedar. (2002), Pokoknya Kualitatif, Rosda, Bandung

Derrida, Jaques. (1974), Of Grammatology, The Jhon Hopkins University Press.

De'Saussure, Ferdinand. (1974), A Coourse in General Linguitics, Fontana, London

Endah, Asih, (2014). Keraton Kasepuhan: Menapaki Semangat Pluralisme, Pikiran Rakyat, Minggu, 24 Agustus2014, Bandung

Habermas, Jurgen. (1990), Modernity An Incomplete Project, Postmodern Culture, London: Pluto Press.

Harland, R.(1987). Superstructuralism, The Philosophy of Structuralism and Poststructuralism, New York, Rotledge.

Hasanudin (2001), Batik Pesisiran, Melacak Pengaruh Etos Dagang Santri pada Ragam Hias Batik, Bandung. Kiblat Buku Utama

Hood, Benny Hoendoro, (2014). Semiotik dan Dinamika Sosial Budaya, Edisi ke-3 Komunitas Bambu, Depok

Irianto, Bambang R. (2009), Makna Simbolik Batik Kraton Cirebon, Tidak diterbitkanalen

Ishwara, Helen, (2011). Batik Pesisir Pusaka Indonesia, KPG (Koleksi Pustaka
Gramedia), Gramedia, Jakarta

Kaplan, David. (1972), Culture Theory, Prentice Hall. Inc. Englewood Clifts New Jersey, USA

Levin, David Michel. (1988)., The Opening of Vision, Routlege

Piliang, Yasraf Amir. (1999), Sebuah Dunia Yang dilipat, Mizan, Bandung

Samsi, Sri Sudewi, (2011), Batik, From The Court of Java and Sumatra,, Techniques, Motifs \& Pattern Bati Yogya \& Solo, Titian Foundation

Sewan, Susanto S., (1980). Seni Kerajinan Batik Indonesia, Balai Penelitian Batik dan Kerajinan, Lembaga Penelitian dan Pendidikan Indusri, Departemen Perindustrian RI

Sturrock, Jhon. (1979), Structuralisme and Since, Oxford University Press

Sudjoko. (1972), Hubungan Desain Batik Dengan Pemasaran, Artikel Seminar, Universita Trisakti, Jakarta

Syamsuri, Baidlowi, (1995) Kisah Walisongo Penyebar Agama Islam di Tanah Jawa, Apollo Lestari, Surabaya

Toekio, Soegeng M., (2000). Mengenal Ragam Hias Indonesia, Angkasa Bandung

Yudoseputro, Wiyoso. (2008), Jejak-jejak Seni Rupa Indonesia Lama, Yayasan Seni Visual Indonesia, IKJ, Jakarta

Yin, Robert, K. (1991), Research Case Study, Sage Thousand Oaks Majalah

Dias, Anton, (2013). Akulturasi Budaya Batik Cirebon; Ketika Kerifan Lokal Melebur Dengan Beragam Budaya,Majalah Sinaya Edisi II April 2013 BTPN 